\title{
Exploring the Image ability of the Central Business District in Sabzevar City, Iran
}

\author{
Mehdi Fallahi Panah ${ }^{1}$, Dr. B. Shankar ${ }^{2}$ \\ ${ }^{1}$ Research Scholar in Urban and Regional Planning, School of Planning and Architecture, \\ University of Mysore, Mysore \\ ${ }^{2}$ Associate Professor of Urban and Regional Planning, School of Planning and Architecture, University of \\ Mysore, Mysore
}

\begin{abstract}
Urban spaces are liveable, vital and perceivable multi-dimensional places. They are formed by buildings and blocks and are perceived by citizens and have many inter-related urban activities in between. The importance of socially active city streets is considered vital not only for people, who use the streets; but it is also important for the health and sustainability of the city. Sabzevar CBD streets have an important role and challenge in place making, therefore, they should be designed or improved as not only being a physical path of connecting various uses but also to create the sense of place for individuals and communities. This paper attempts to find out the user's perceptions and mental images related to SabzevarCenral Business District (CBD) and, the spatial image, cognitive urban image was used for study of urban design elements.
\end{abstract}

Keywords: Imageability, Mental Image, Street, Path, Land Mark.

\section{INTRODUCTION}

Streets are an integral part of cities and must satisfy a multitude of functions. "The one public service we all use every day are the streets where we live" [1].Streets can be seen as stretches of movement or alternatively the street can be seen as a public space where people can work and socialize. A Street comprises the entire threedimensional visual corridor, including the public realm and it relates and reacts to the adjacent land uses.The importance of a street as a public open space is one of the most critical characteristic within the public realm in cities [2]. It is increasingly recognized that effective urban public spaces are crucial to health, happiness, democracy and even the urban economy [3]. Social activities in urban open spaces are increasingly been used as a measurement of the city vitality and overall liveliness. As such these attributes can also be seen as a "direct indicator of the satisfaction of the people within their physical surroundings" [5]. Streets account for about $60 \%$ of public spaces and they account for a greater amount of developed urban land directly controlled by the public and communities [6].
Lynch described the identity as the physical or experiential character of a place which permits users to distinguish that place from adjacent spaces or places. An image of the city centre provides easily and quickly access to the users and built a familiar image within the space and may create a large frame of references to address a locality which surely enhances safety and human experience. Therefore, the components which create accurate images to the city form are: "path, edge, district, node and landmark" [6].By considering these five elements, the perspective, sequence, axis and corridors can be pointed out which aides in identifying the Sabzevar CBD streets characteristics.Here Lynch's approach for analysis of the visual forms of Sabzevar city is carried out to understand and develop the image of city. A clear mental map of Sabzevar urban environment is needed to represent the characteristics of urban streetscape. This mental map represents an important sense of emotional security of the people, who are happened to be the ultimate users of urban streets and it is the framework for communication and conceptual organization, and heightens the depth and intensity of everyday human experience within the city center. Sabzevar city itself is thus a powerful symbol of a complex society.

The effects of the physical qualities of Sabzevar's streetscapes within the boundaries of CBD and their effects on liveability and quality of the streets is to gain a better understanding of the study analyses the imageability of Sabzevar CBD.Special emphasis is placed on streets to find out the imageability of city centrewhich takes into account all users and not only motor vehicles. These streets accommodate social interaction, encourage pedestrian activity or serve as a social network.Urban qualities are important for active street life, imageability is the urban design qualityoperationalized in this study.Imageability is the quality of a place that makes it distinct, recognizable, and memorable. A place has high imageability when specific physical elements and their arrangement capture attention, evoke feelings, and create a lasting impression.Identificationof 
Lynch elements and his physical attributes was fulfilled based on a comprehensive field observation. Through structured observations and pictorial surveys, the imageability of casestudy area was evaluated and the elements were discovered.The purpose of this research is to create a greater understanding of thepublic's experience and behavioural patterns in creating socially active streets.

\section{BACKGROUND OF SABZEVAR CITY}

Sabzevar is a city in Northeast Iran, situated in Razavi Khorasan province with geographical coordinates of $36^{\circ} 12^{\prime} 52^{\prime \prime}$ North and 57 40' 47" East. Sabzevar city area has an extent of about 2676 sq. $\mathrm{km}$ and it is located approximately 220 kilometers at west of Mashhad, the provincial capital and also 670 kilometers at east of Tehran, capital of the country. In an average the city is elevated 960 meter above the sea level, lowest of 940 meter in the south and highest of 1150 meter in the northern part of the city. The general slope is from north to south and varies from 0 to 3 percent. As per 2006 census, the city's population was 208,172 , in 57,024 households and increased to 231,557 in 2011 .

\section{CENTRAL BUSINESS DISTRICT}

The CBD area is defined by the boundaries of main streets proposed in municipal plan. AsadAbadi Street in the north, Kashefi in the east, Atamalek Street in the west and Modares Boulevard in the south forming the CBD borders. The CBD has residential share of 11.48 percent of the total city population and many of its plots have been converted to commercial or administrative offices. Sabzevar city center is a complex agglomeration of multiple activities such as economic, social, cultural, etc. that are all joined by a web of streets as medium of connection under influence of traffic and transportation with different roles. Besides being the commercial core, the CBD serves as retail district flanked by stores, shops, office buildings, banks, hospitals, mosques and religious places, schools, hotels and organizational headquarters.Sabzevar city center consists of six major street classified by Sabzevar urban authority. Among all the CBD streets, Beyhagh and Kashefi streets are acting as focal point for shopping and retailers and are most often used in reference to retailing and socializing.

Figure 1: CBD of Sabzevar City

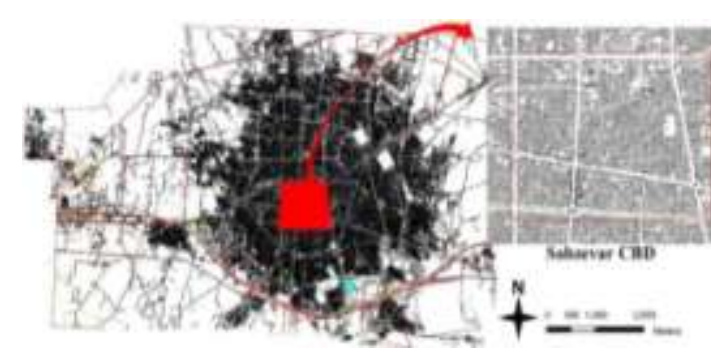

\section{IMAGE OF SABZEVAR CITY}

Kevin Lynch innovation was the concept of place legibility, which in fact is the facility for people to understand the layout of a place. By introducing this idea, Lynch was able to isolate distinct features of a city and see what specifically is making it vibrant, and attractive to people. People first create a mental map to understand the layout of a city. Mental maps of a city are mental representations of what the city contains, and its layout according to the individual. These mental representations, along with the actual city, contain many unique elements, which are defined by Lynch as a network of paths, edges, districts, nodes, and landmarks. First, paths are channels by which people move along in their travels. Examples of paths are roads, streets, trails, and sidewalks. Edges are the second elements which are all other lines not included in the path group for examples walls and seashores. The districts are parts of the city that are relatively considerable in size having an identifying character about them. Nodes being the fourth element, are points or strategic spots where there is an extra focus or added concentration of city features including a busy intersection or a popular city center. Finally, landmarks are external physical objects that act as reference points. Landmarks can be any physical object that aids in orientation in way-finding such as store, mosque, mountain, school, etc.Lynch elements help the users to understand the surrounding area in consistent and predictable ways and helps in forming a mental maps.

a) Paths, the streets, sidewalks, trails, and other channels in which people travel;Paths or streets are predominant elements of imageability for most of the people. Street forms the basic path and division system of area in layout of the city. They include roads, street system, pedestrian walkways, transit lines, etc. the routes or channels along which people or observer potentially or customarily moves. Paths are one of the influential elements in making image in people's mind. And change of paths can make different qualities of view. This study identifies Beyhagh, Kashefi, Asrar and Atamalek streets as the most important paths within the boundary of CBD. Due to their important functional role and great amount of vehicular and pedestrian movement in these streets 
they form an important part of citizen's perceptual body. Beyhagh is the most important path among all the CBD streets as being located next to the old city market. Kashefi, AsadAbadi, Asrar, Modares and Atamalek streets stand in the second position of importance. It should be noted that, due to the presents of abandoned-inactive large grain plots in the paths of Atamalek and Modares, they are having lesser level of importance, but however, their bold role of mobility have kept them in the perceptual map of citizens. Streets like Farmandari, Ghaem, ShariatMadar, Basij are in great distance of importance from the mentioned paths. Even though some of them act as commercial axis but still they are not considered to be important paths since they don't have strong mobility role. The last position of paths forming the environmental perception are side streets that are having completely local role and are not considered in the city level cognitive map except in the perception of residents of each alley. These paths have been shown in different colors in the figure 2 .

Figure 2: Paths in Sabzevar CBD

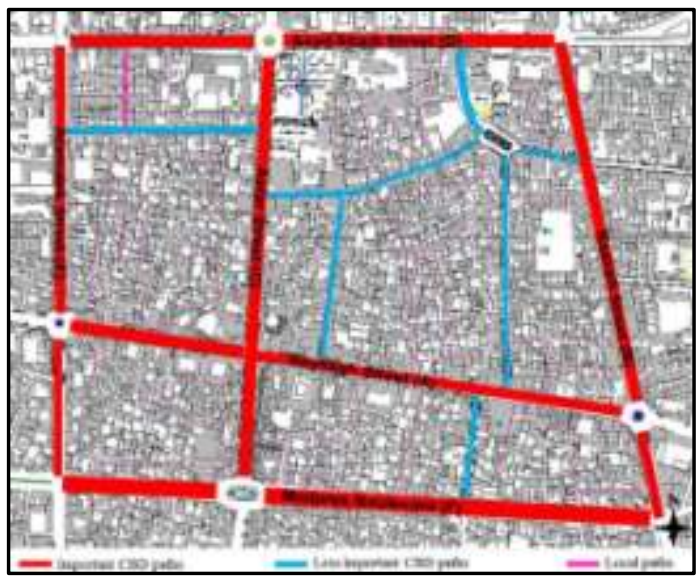

Identification of these paths is important to locate the specific function of the CBD axis and streets leading to them. In addition for enhancement of streets performance it can enrich the perceptual map of citizens. The streets of CBD are the paths that each consecutive sequences of them have different qualities. The main features of these sequences are:

a) Meaning (sense): the meaning and significance role of mental urban location can be seen in the rich architectural and historical elements laid out in the CBD streets. A great example is the Jama mosque and Imam Zadeh Yahya in Beyhagh Street.

b) Congruence: can be seen in the building with common sequences which have similar features. This feature can be seen in the Beyhagh and Asrar streets where the blocks are following the same height, material and façade covering, specifically the commercial units of Beyhagh stretch.

c) Centrality: can be seen in the sequences where the building is tall or the path width is small. Centrality could be found in the Kashefi, Asrar and AsadAbadistreets where the tall mass such as hospitals, department of education or the headquarter office of city municipality is placed alongside a narrow path.

d) Emphasis:it existsin the pathways which has especial element in it such as mosque. The Pamenar mosque in BeyhaghStreet is an example.

e) Openness and narrowing: it would occur due to the organic character in few of the sequences which causes spatial variation. These type of scenery can be found in the old tissue of the city in Beyhagh and Asrar streets, especially where a secondary road connects to the main street.

Figure 3: Features of Sabzevar CBD Paths

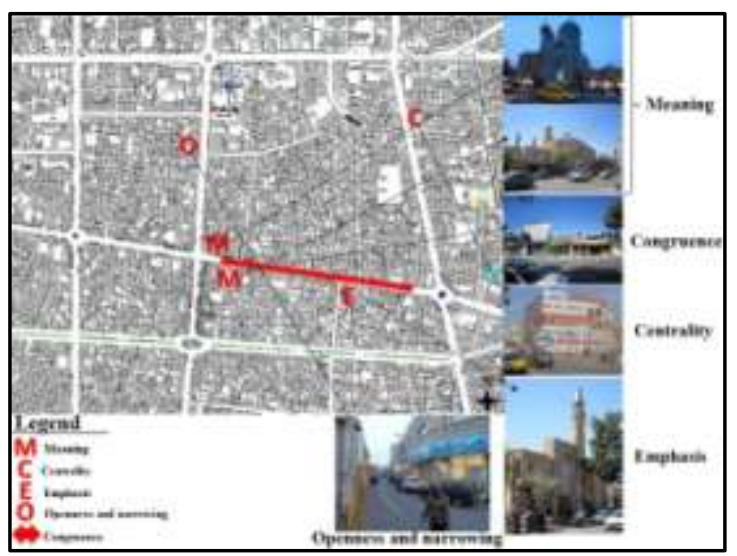

Street is understood to be continuous and impacts of each sequence on human mind gives him an overall image of the space. Placement of each sequence next to another would create the view for people.In the CBD area the shops, offices, public units and etc. have been located on the either side of the main streets which define the quality, function and even the character of the pathway. The building material used in these buildings varies from street to street, in the old streets such as Beyhagh and parts of Asrar, the common used material on the elevation is brick and in some older buildings is claygiving them a predominant red color with cream accents, distinct patterning due to the size of the brick and unique textural quality.But the facade in Kashefi, AsadAbadi, Modares and Atamalek is treated with more contemporary materialssuch as stone cladding, aluminum panel and glass combination or rowlocksince the buildings are new. 
Figure 4: Building Façade in Sabzevar CBD Paths

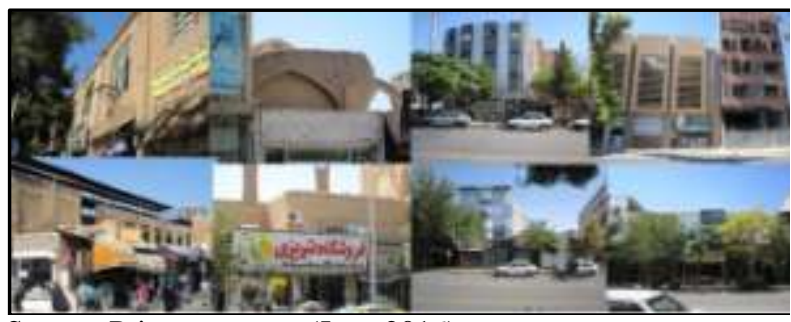

Source: Primary survey (June 2016)

Damages to the old parts, mistreatment in conservation and pollution have resulted in poor quality facade that have reduced the visual qualities within the old Sabzevar streets. Many of the single storey buildings in the streets of Beyhagh and Asrar are the example of such unpleasant view in Sabzevar CBD (Fig. 4).In some buildings valuable architectural elements such as railings, woodturning and bricklayer can be seen while lack of appropriate pattern causes disturbance in the walls and components.

b) Edges, perceived boundaries such as walls, buildings, and shorelines; Edges and bodies are important due to the creation of character and quality of urban open spaces such as streets. Apart from physical character of each section, the human activities also would affect the character and quality of the space.Edges are the linear elements which are not considered as paths by observer. These can be the boundaries between two phases or two paths, linear break in the continuity such as cuts, edges of development, walls, natural barrier such as mountain chain or shores, etc. They may be permeable through perforations, breaks, etc. [6]. They predominantly comprise of walls and facades. Especially in Sabzevar old bazaars or shopping street. In a holistic view, the edges of the CBD and its surrounding streets can be classified as:

a) The old market which used to be the backbone of the city and even today is one of the fictional edges at the Asrar Street. The historical edges and its vibrant mixed land use with presence of street hawkers have created an extra vitality in this area.

b) The commercial edges of Beyhagh and Kashefi streets are occupied with different commercial activities, for example the Beyhagh commercial occupants are toggery, fabric store, jewelry, retail shops, home appliances whereas Kashefi is more about electronic appliances, mobile phones, fashion store and Asrar is basically occupied by shops which sells tools and agricultural and farming supplies beside of having some other commercials unit. In addition, other commercial activities in city center are not centralized or channelized as it is in these streets and other CBD streets hardly create a commercial image for people. These elements together would create the commercial tissue of the Sabzevar city center.The commercial line of the Beyhagh Street is one of the most active parts of the Sabzevar city. The excess of goods and activities in this part have also created a lively path. In the streets of AsadAbadi, Modares and Atamalek the commercial lines is broken with less activities taking place.

Figure 5: Edges in Sabzevar CBD

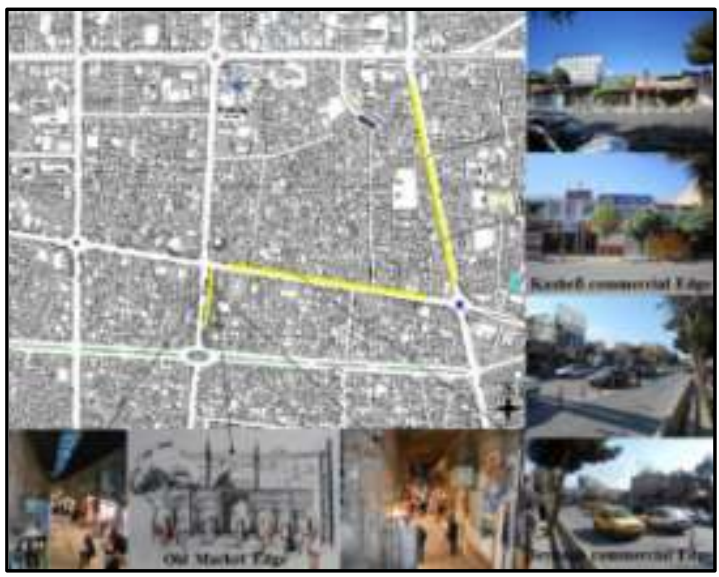

c) Landmarks: readily identifiable objects; Sabzevar CBD is situated in the historic-old part of the city and has buildings with great historical and architectural values, therefore, any of such monuments can be considered landmark within the entire city center. Landmarks are the point of references and are externally defined features or physical objects such as buildings, activity centers, monumental objects or natural elements such as mountains, river, tree and etc. some landmarks may also have directional attributes or some are the distant ones i.e. seen from many angles and distances [6].The major landmarks of the city comprises of:

a. City landmarks: The Memarzadeh caravansary, Jama mosque, Pamenar mosque, Imam Zadeh Yahya, Sabzevar hospital, department of justice, Sabzevar main post office are the important landmarks of this area. The view of the tall minarets in the mosque is also another view point and landmark of the CBD area. These minarets can be seen from surrounding streets and are one of the indicators of Beyhagh Street. But due to violation of height restriction in city center in some streets this perception is not achieved today. These landmarks act as community identity and are perceived by the entire citizens and not only CBD dwellers.

b. Local landmarks: These landmarks are recognized only by the local dwellers of CBD and are not considered in city cognitive map. 
The tall trees of Asrar Street in front of caravansary is an example of local landmarks which happens to be the meeting point for Golestan dwellers. Ali Akbari Husseiniyahs near Beyhagh Street is another example of local landmark.

Figure 6: Landmarks in Sabzevar CBD

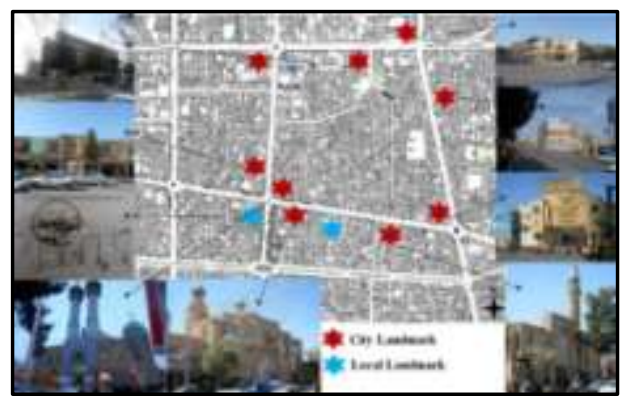

Among the landmarks of the city center, Imam Zadeh Yahya and Jama' mosque are the most significant landmarks as an urban elements. Imam Zadeh Yahya is located at the Asrar-Beyhagh junction and the Jama' mosque is placed at the southern side of Beyhagh Street. These two elements can be seen from different points of the surrounding streets due to the height advantage.Visual connection to the Imam Zadeh Yahya provides the sense of identity for the citizens.

Figure 7: Imam Zadeh Yahya and Jama Mosque as the Community Identity in Sabzevar CBD

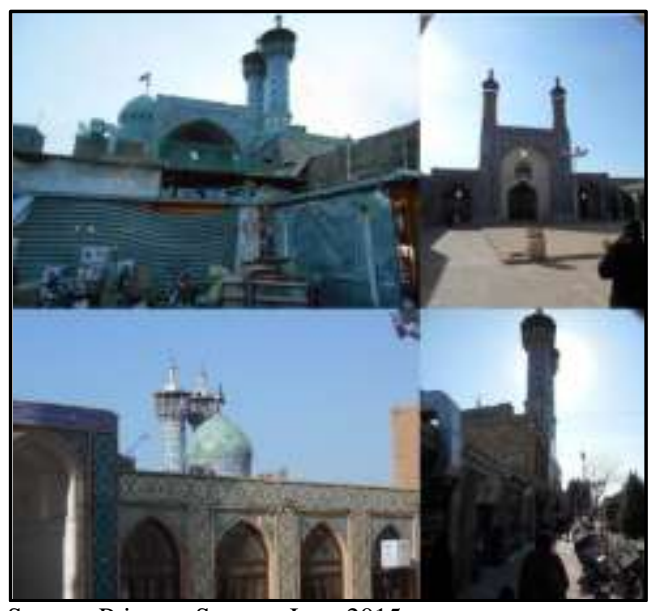

Source: Primary Survey, June 2015

d) Nodes, focal points; Nodes are the points of the intensive foci along the paths in the city through which the observer is travelling. They are the strategic spots in the city into which he can enter, and are primarily the junctions, crossing or convergence of the paths, places of break in the transportation, moments of shift from one structure to another, etc. [6]. Generally few nodes can be identified in Sabzevar CBD streets but the nodes which create gathering spaces are having decisive role. In addition in creating an image of the city, these nodes reinforce the collective identity of the people and even the social interaction gets deeper dimension among citizens. These nodes in heart of Sabzevar city have been shaped through different ways.

- Confluence of several paths: such as 22 Bahman square that brings the important paths of city in one point as shown in the figure 8 below. Another prime example of such node, is the Beyhagh junction connecting the southnorth and east-west traffic together. Dadgostari junction is also an important node in the north of CBD that brings out the south volume to north and distributes it to west and north direction. The important node in the west is Iraq square which confluences the east-west traffic and south-north movement. It is the largest node at the west of city center.

- The space in front of some important buildings also can be considered as social nodes where people can sit and chat for break time such as the area in front of municipality office or in front of the Sabzevar national park.

Figure 8: Nodes in Sabzevar CBD

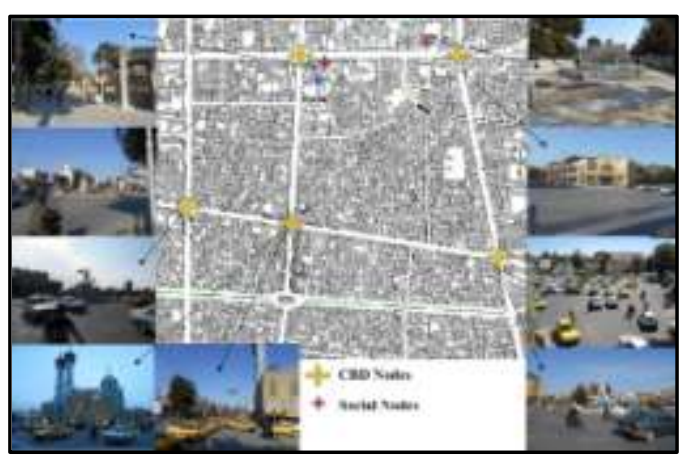

e) Districts, relatively large sections of the city distinguished by some identity or character; Districts are one of the important elements of shaping an area which would create a clear image of the place in the people's mind. In Sabzevar CBD area the following spaces are identified as important districts: 1 . the commercial or business districts and, 2. the residential districts.

1. The commercial or business district: these districts are located mostly in the south and eastern part of the city center specially through the streets of Beyhagh and Kashefi which can be identified as:

a. Workshop district-producers which are producing the agricultural tools for villagers are found in the street Western wing of Beyhagh and South Asrar axis within the city center.

b. Shopping district which are placed in the extreme southern and eastern part of city center and include the street of Beyhagh and 
Kashefi. These districts are the most crowded districts in CBD and have an especial value during the cultural ceremonies and shopping festivals.

2. Residential districts: the residential district also like commercial district is consisting of two parts. A: the first part is the residential district behind the commercial zone where the residential units are placed at the background of commercial district and are accessed by the narrow connecting alleys. The residents of this part are mostly the local people and they are generally engaged with jobs happening around the district. This type of residential districts can be seen in the southern part of CBD in the old tissue, specifically located in street Beyhagh, Kashefi, Asrar and Modares. B: the second part is the residential portion mixed in with public zone, where the residential units are placed along the main streets and mixed with public uses or commercials. In some cases the building in ground floor is the publiccommercial unit and is residential in upper storey or vice versa. Such districts are visible in street AsadAbadi, Atamalek, Asrar and Modares.

Figure 9: Commercial District of SabzevarCity Center

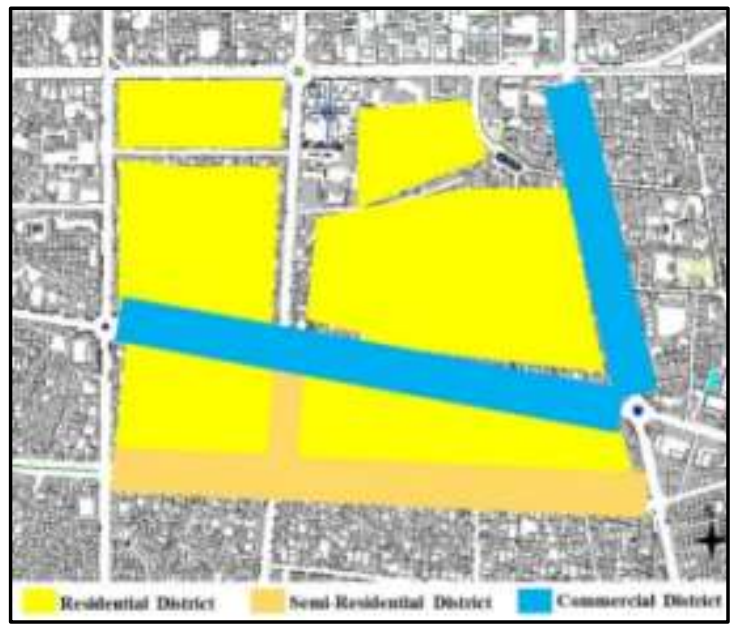

\section{DISCUSSION}

An environmental image represented using the five elements has three components of:

Identity which is the recognition of urban elements as separate entities such as streets, architectural monuments and etc., (

Structure which is the relation of urban elements to other objects and to the observer, for example the Islamic architecture style among the CBD monuments, and

c) Meaning which is the practical and emotional value to the observer, i.e. the religious-holy place of CBD.It is important to know that these urban elements are not hermetically designed into precise and final detail but presented in an open-ended order. Lynch elements are an agenda for understanding urban streetscape character and urban imageability (Fig. 10).

Figure 10: Mental Map of Sabzevar City Center

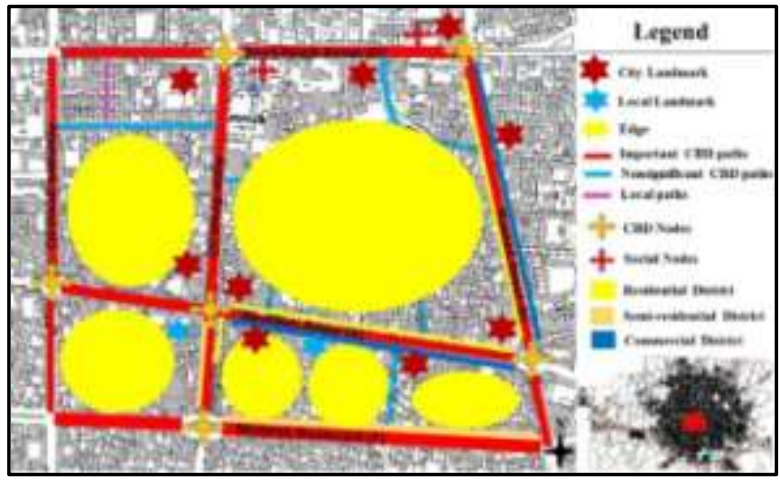

The analysis has demonstrated that even though the CBD streets are the standard connecting web in Sabzevar city but they have a social function in creating imageability and mental map within cultural context. Main streets in Sabzevar $\mathrm{CBD}$, beside of serving the primary purpose of access and mobility offer more than just being a pathway by creating a series of connected activities and spaces as being addressed in the mental map (Fig. 10). Main CBD streets in Sabzevar function for the reason of access and mobility as well as providing active places, creating a stage for the variety of social, commercial and cultural activities aiding in enhancing public life.

\section{CONCLUSIONS}

Building the image of any environment is a two way process and is the result of an interaction between the observer and the environment. In the streetscape scenario in the heart of Sabzevar, it is not about how the things are seen, but it includes everything as part of street environment. The analysis of the five imageability elements tried to understand how people perceive, inhabit and move around in the Sabzevar urban scape. It shows that streetscape in Sabzevar CBD is not just composed of the physical characteristics but equally is the representations of mental images. Mobility is not just free-flowing movement but heavily relies on city center structure and identifying the environment through the aid of mental maps. The study shows that streets role and challenge of street in place making is an important forgotten function.Therefore, the street need to be designed not only as a physical means of connecting various uses and people, but also, in how these features can be important in the evolution of sense of place for 
individuals and communities. To improve the street role in place making, the streets need be designed in such a way to encourage social contact and aid uninterrupted social activity. So, function has to be considered in Sabzevar CBD streets design rather than just visual appearance. Indeed,Sabzevar CBD streets to be considered people oriented, rather than being focused on the needs of the automobile.

\section{REFERENCES}

[1]. Government of South Australia (2012) Street for People: Compendium for South Australian Practice Adelaide, Government of South Australia.

[2]. Gehl, J. (1987) Life Between Buildings: Using Public Space (Copenhagen: The Danish Architecture Press).

[3]. Shaftoe, H. (2008) Convivial Urban Spaces, London, Earthscan.

[4]. Mehta, V. (2007) Lively Streets: Determining Environmental Characteristics to Support Social Behavior, Journal of Planning Education and Research, 27(2), pp. 165-187.

[5]. Jacobs, A. (2010) The Importance of Streets. In: Kang H. C, L. B. Liang and H. Limin (Ed) Asian Streets and Public Space. pp. 159-169 (Singapore: National University of Singapore).

[6]. Lynch,K. (1960) "The image of the City", Cambridge, Mass: MIT Press.

\section{BIOGRAPHIES}

Mehdi FallahiPanah, received B.Arch. degree from University School of Design, University of Mysore, India in Architecture in 2010, M. Tech. degree in Urban and Regional Planning from University of Mysore, India in 2012. Currently he is pursuing Ph.D. in Urban \& Regional Planning in School of Planning and Architecture, Mysore. His research interests include Urban planning, Urban design, Slum development, Traffic and Transportation, Streetscape and Street design analysis and function.

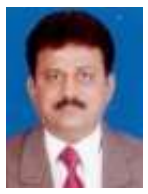

B. Shankar received the B.E. degree in Civil Engineering in 1984, M.U.R.P degree in Urban and Regional Planning in 1989 and Ph.D. degree in Urban and Regional Planning in 1997 from the University of Mysore, Mysore. $\mathrm{He}$ is working as Associate Professor in Urban and Regional Planning at the Institute of Development Studies, University of Mysore, Mysore. His research interests include Urban Planning, Spatial and Land Use Planning, Community Development, Heritage Conservation, and Planning Legislation. 